\title{
Updated morphological description of Asteroporpa (Asteroporpa) annulata (Euryalida: Gorgonocephalidae) from the Brazilian coast, with notes on the geographic distribution of the subgenus
}

Descripción morfológica actualizada de Asteroporpa (Asteroporpa) annulata (Euryalida: Gorgonocephalidae) de la costa brasileña, con notas sobre la distribución geográfica del subgénero

\author{
Anne I. Gondim ${ }^{1}$, Thelma L. P. Dias ${ }^{2}$ and Cynthia L. C. Manso ${ }^{3}$ \\ ${ }^{1}$ Universidade Federal da Paraíba, Programa de Pós-Graduação em Ciências Biológicas (Zoologia), Laboratório de Invertebrados \\ Paulo Young, Departamento de Sistemática e Ecologia, Campus I. Cidade Universitária, CEP 58051-900, João Pessoa, PB, \\ Brasil. anneisabelley@yahoo.com.br \\ ${ }^{2}$ Universidade Estadual da Paraíba, CCBS, Departamento de Biologia, Campus I, Rua Baraúnas, 351, Bairo Universitário, \\ CEP 58429-500, Campina Grande, PB, Brasil \\ ${ }^{3}$ Universidade Federal de Sergipe, Laboratório de Invertebrados Marinhos, Departamento de Biociências. Av. Vereador \\ Olimpio Grande, S/N, CEP 49500-000, Itabaiana, SE, Brasil
}

\begin{abstract}
This study provides an updated morphological description of Asteroporpa (Asteroporpa) annulata based on one specimen from the northeastern coast of Brazil, thus validating the previously uncertain occurrence of this species there. We also provide notes on the known geographic distribution of the subgenus Asteroporpa (Asteroporpa) and comments on ecological aspects of this taxon. Given our limited knowledge of the Euryalida fauna along the Brazilian coast, these new records are important for understanding the distribution, dispersal and speciation patterns of this group. The number of Euryalida reported for the Brazilian coast is increased to eight with this record.
\end{abstract}

Key words: Echinodermata, taxonomy, ophiurans, geographical distribution

\section{INTRODUCTION}

The order Euryalida represents a group of brittle stars, commonly known as basket stars or snake stars, which have worldwide distributions but are not readily encountered because they mainly inhabit deep ocean waters (Hyman 1955). Most species are epizoic and live on other animals such as gorgonians, antipatharians and sponges, but are also occasionally found attached to hard substrates. Euryalida have traditionally been considered a primitive group (Matsumoto 1917, Fell 1962, Baker 1980), although Hendler \& Miller (1984) noted that they possess the most specialized morphological attributes in the class Ophiuroidea, including the presence of vertebrae with streptospondylous-type joints that allow them to move their arms vertically.

Euryalida appear to be generally scarce, and they occur below the typical depth range of SCUBA-assisted research. Because of this limitation, along with the general paucity of useful taxonomic characters in Euryalida, our knowledge concerning this group has advanced more slowly than in other echinoderm taxa (Baker 1980). Of the three families in this order (Asteronychidae Müller \& Troschel, 1842, Euryalidae Gray, 1840 and Gorgonocephalidae Ljungman, 1867), only Euryalidae and Gorgonocephalidae have been recorded on the Brazilian continental margin (Tommasi 1999, Stöhr \& O’Hara 2007).

The Gorgonocephalidae represent the culmination of euryalous-type structures (Hyman 1955), and their species have wide bathymetric and geographic distributions, occurring from shallow waters to deep ocean areas (Rosemberg et al. 2005, Barboza et al. 2010). The family was established by Ljungman (1867) and is characterized by having skin that is usually tuberculate, as well as simple or branching arms having rows of hooks on their dorsal surfaces (Ljungman 1867, Verrill 1899, 1900). These hooks lack a lamina and have serially arranged holes (Mortensen 1933). According to Stöhr \& O'Hara (2007) the family Gorgonocephalidae comprises 38 valid genera, of which only Astrochele Verrill, 1878, Astrocyclus 
Döderlein, 1911, Astrogomphus Lyman, 1869, Astrotoma Lyman, 1875 and Astrophyton Fleming, 1828 have been cited for the Brazilian coast (Barboza et al. 2010). Recently, the genus Gorgonocephalus Leach, 1915 was found on the southern coast of Brazil (Barboza et al. 2010). Only seven species of the order Euryalida were recorded for Brazil, namely Ophiocreas lumbricus Lyman, 1869, Astrochele lymani Verrill, 1878, Astrocyclus caecelia (Lütken, 1856), Astrogomphus vallatus Lyman, 1969, Astrophytoun muricatum (Lamarck, 1816), Astrotoma agassizii Lyman, 1875, and Gorgonocephalus chilensis (Philippi, 1858).

Data concerning species occurrences are essential for understanding their distribution, dispersal, and speciation patterns (Grohmann 2006), but there is a good deal of unconfirmed information to be found in the literature. An example of this situation is the gorgonocephalid Asteroporpa (Asteroporpa) annulata Örsted \& Lütken in Lütken, 1856, which was reported for Brazil, where no publication by any Brazilian author or any other scientific collection has since validated the occurrence of this species in Brazil. Only Hendler et al. (1995) included Brazil within the area of occurrence of this species, while other authors (e.g., Appletans et al. 2010) considered only North Carolina, Bermuda, the Gulf of Mexico, the Caribbean Sea, the Bahama Islands, and Colombia as being within its geographic range. As such, this work provides the first reliable record of the occurrence of Asteroporpa (Asteroporpa) annulata in Brazil, and offers a detailed description of the material examined; we also discuss the geographic distribution of this species as well as of other species of this subgenus.

\section{Materials AND Methods}

The present study was based on one individual of Asteroporpa (Asteroporpa) annulata captured by a fisherman using a hook and line. It came from the continental shelf about $40 \mathrm{~km}$ off shore of Macau city, along the northern coast of Rio Grande do Norte State, NE Brazil (4'42'09.9"S, 36 $28^{\circ}$ '08.2"W) at a depth of approximately $100 \mathrm{~m}$.

The taxonomic identification of this animal was based on the descriptions by Clark (1948) and Hendler et al. (1995). The disk diameter was measured using a digital EDC 6" caliper, and the specimen was photographed using a Canon A640 10MP digital camera coupled to a Nikon SMZ800 stereomicroscope and to an Olympus BX41 microscope.
The specimen examined was fixed in $70 \%$ ethanol and deposited in the Echinoderm Collection of the Paulo Young Invertebrate Collection (UFPB/ECH), Department of Systematics and Ecology, Federal University of Paraíba, Brazil.

\section{RESULTS AND DISCUSSION}

\section{Systematics}

Order Euryalida Lamarck, 1816

Family Gorgonocephalidae Ljungman, 1867

Asteroporpa (Asteroporpa) annulata Örsted \& Lütken In: Lütken, 1856

\section{Material examined}

UFPB/ECH.1823, 1 spec., 4²4'09.9"S, 36²8'08.2"W, Macau, Rio Grande do Norte, Brazil, approximately $100 \mathrm{~m}$ deep.

\section{Description \\ DISK}

The specimen examined has a pentagonal disk $18.37 \mathrm{~mm}$ in diameter, covered dorsally by a thick skin (Fig. 1A). The radial shields and their surroundings are tumid (Fig. 1C), long (4.47 mm), bar-like, extending more than half of the disk diameter, and covered by five rows of rings with sharp granules (Fig. 1C). The periphery of the dorsal disk is covered by flat, sometimes polygonal, plate-shaped dermal ossicles. The dorsal center of the disk is occupied by large, flattened plate-shaped dermal ossicles. The lateral interradial surface of the disk has flattened, irregular-sized, and slightly imbricate plate-shaped dermal ossicles.

The disk is thickened by a hump at the juncture of the disk and the base of each arm; this hump-like appearance is due to bar-like radial shields. The dorsal surface of the disk has the same pattern as the arm, with clear rows of hooklet-bearing plates alternating with dark depressed areas. The jaws and ventral surface are covered by a thick skin, and show small, flattened dermal ossicles (Fig. 1B), similar to those observed on the radial shields. Sometimes there are numerous sharp cone-shape dermal ossicles on the adoral shields going toward the periphery of the oral surface of the disk. The genital slits are wide $(0.8 \mathrm{~mm})$ and long $(1.85 \mathrm{~mm})$, occupying almost the entire length of the interradial region. The jaws are armed with spiniform teeth arranged in up to three horizontal rows on each side of the jaw (Fig. 1E). 
ARMS

There are five arms that are not branched and not clearly distinct from the disk. The dorsal and lateral surfaces of the arms are annulated (Fig. 1F), with inflated, white and transverse rows of hooklet-bearing plates. The areas between the rows of hooklet-bearing plates are depressed and brown to cream in color toward the distal portion of the arms. Each hooklet-bearing plate has two rows of numerous microscopic hooklets (Fig. 1G) that have two curved lateral teeth (one longer terminal tooth and one short inner tooth) (Fig. 1H). There are numerous flattened and juxtaposed plate-shaped dermal ossicles (similar to those of the disk) in the depressed areas between the brachial rows of hooklet-bearing plates. The tentacle pore is wide and without any tentacle scales. The arms have six short arm spines $(0.88 \mathrm{~mm})$ corresponding to approximately one brachial segment, with the innermost one being the largest. There is a crown of up to four hyaline denticles at the end of each arm spine. The number of arm spines decreases toward the end of the arm, where only one arm spine with 3-5 lateral arm spines is observed. The arm spines arise from the ventral surface of the arm (Fig. 1D).

Figure 1. Asteroporpa (Asteroporpa) annulata. A: dorsal view; B: ventral view; C: detail of the radial shield; $D$ : ventral view of the arm; $E$ : detail of the jaw; F, dorsal view of the arm; G: detail of the brachial rings, showing two dorsal and lateral rows with numerous and microscopic hooks; $\mathrm{H}$ : microscopic hooks (optical microscopic image) / Asteroporpa (Asteroporpa) annulata. A: vista dorsal; B: vista ventral; C: detalle del escudo radial; D: vista ventral del brazo; E: detalle de la mandíbula; F: vista dorsal del brazo; G: detalle de los anillos braquiales, mostrando dos filas dorsales y laterales con ganchos numerosos y microscópicos; $\mathrm{H}$ : ganchos microscópicos (imagen de microscopio óptico)
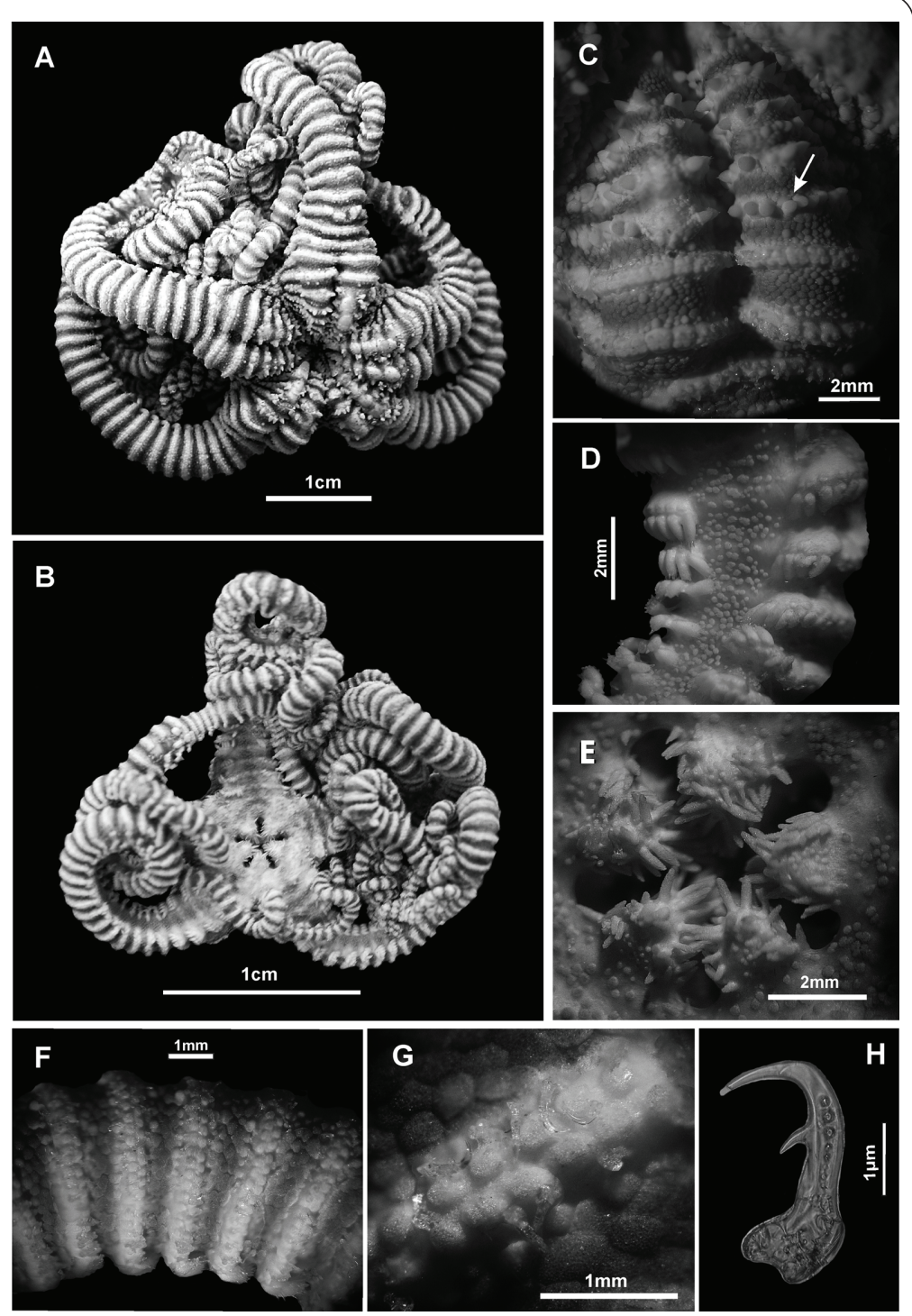

Vol. 47, №1, 2012 


\section{Distribution}

North Carolina, Bermuda, Bahamas, Gulf of Mexico, Caribbean Sea - Colombia, Cuba, Mexico, Puerto Rico (Borrero-Pérez et al. 2008, Alvarado 2011), Panama, Mexican Caribbean (Laguarda-Figueras et al. 2005), and Brazil (present study).

\section{HABitat AND ECOLOGY}

Asteroporpa (Asteroporpa) annulata generally lives in association with live corals and gorgonians (Hendler et al. 1995), which they grasp with their movable arms. Hendler \& Miller (1984) recorded this species found attached to colonies of the hard coral Oculina varicosa in Florida, with one or more arms coiled around the coral branches; McClintock et al. (1993) collected hundreds of individuals on rhodolith beds in the Gulf of Mexico. In the same locality, Viada \& Cairns (2007) found $A$. (A.) annulata coiled on the branches of the octocoral Nicella toeplitzae. The specimen examined in the present study provided no clues concerning the substrate to which it had been associated. However, anecdotal information obtained from fishermen suggests that the study area is rich in gorgonians and sponges.

According to McClintock et al. (1993), most of the 177 specimens of Asteroporpa (A.) annulata they studied from the Gulf of Mexico were adults. A few smaller individuals with disk diameters less than $9 \mathrm{~mm}$ were found clinging to adults. Hendler et al. (1995) suggested that live individuals move slowly and are more active at night. Analyses of the stomach contents of 34 specimens indicated that their diet was composed of copepods and other planktonic organisms (Hendler \& Miller 1984).

\section{REMARKS}

Asteroporpa (Asteroporpa) australiensis differs from $A$. (A.) annulata in the following morphological characters: having narrowly separated, raised, white plates bearing 4-12 small conical tubercles mostly tipped with a glassy thorn in the dorsal center of the disk; also having short, half-moon shaped genital slits (Baker 1980). Asteroporpa (A.) pulchra. Clark, 1915 differs from $A$. (A.) annulata in the following morphological character: the absence of lines of tubercles or hooklets across the radial shield, except at the distal ends (Clark 1915, 1948). Asteroporpa (A.) lindneri Clark, 1948 and A. (A.) annulata are distinguished by having four or five arm spines. Asteroporpa (A.) affinis Lütken, 1859 differs from $A$. (A.) annulata in the following morphological characters: having a broad radial shield, much broader than the bases of the arms; and their oral sides are sparsely granulated (Clark 1948).
Considering the species of the subgenus Asteroporpa (Astromoana), other differences are also evident, such as: in A. (Astromoana) indicus Baker, 1980, the lateral inner teeth of the microscopic hooklets are short and straight, and the terminal tooth is extremely thin. In $A$. (Astromoana) reticulata Baker, 1980, there are four (occasionally five) short arm spines, cylindrical, with 1 or 2 terminal points, and a reticulated pattern of pink and white granules that is almost totally hidden by the radial shield (Baker 1980, Okanishi \& Fujita 2011). A. (Astromoana) hadracantha Clark, 1911 differs from $A$. (Asteroporpa) annulata in the following morphological characters: having six very obvious primary plates in the center of the disk; fine granulation; and very short, thick arm spines (Clark 1911, 1948). Finally, the recently described species A. (Astromoana) muricatopatella Okanishi \& Fujita, 2011 and A. (Astromoana) koyoae Okanishi \& Fujita, 2011 differ from A. (Asteroporpa) annulata in that the first species has arm hooks with two lateral teeth, while the second has three lateral teeth on a hooklet on the basal portion of the arm.

Asteroporpa (Asteroporpa) annulata is the typespecies of its genus, and was described by Örsted \& Lütken (1856) based one specimen with a disk diameter of $11 \mathrm{~mm}$, collected off the western islands of the Caribbean (West Indies); its original description was very brief. These authors merely provided a brief characterization of the radial shield, highlighting the presence of these irregular tubercles, and inflated rows of hooklet-bearing plates in the arms. In 1862, Dujardin \& Hupé described a new species from Guadeloupe, which they named Asteroporpa dasycladia; this animal was subsequently recognized by Lyman (1882) as a synonym of $A$. (A.) annulata (Clark 1948). Clark (1915) described Asteroporpa pulchra in a review of some specimens that had previously been identified by Theodor Lyman as $A$. annulata; however, Lyman had written on the back of one label: 'Does Astrocnida sometimes not fork?', indicating his doubts about the species identification.

Although Asteroporpa (A.) annulata is a relatively common species in the Caribbean region and has been studied in terms of its growth, reproductive biology, population structure (McClintock et al. 1993) and feeding behavior (Hendler \& Miller 1984), detailed taxonomic descriptions of this species are extremely rare. This situation is not restricted only to the species in question, but rather to the entire genus, as identification keys are scarce and since the key developed by Clark (1948) is considered unreliable (Hendler et al. 1995). 
Regarding its area of occurrence, the subgenus Asteroporpa (Asteroporpa) is distributed, with four of its species occurring in the Western Atlantic (the Americas) and two species the Pacific Ocean (Japan, Australia, and New Zealand). Among the Atlantic species, A. (A.) annulata has the largest distribution area, occurring from North Carolina to northeastern Brazil but more so in the Caribbean region. The other three Atlantic species (A. (A.) affinis, A. (A.) lindineri and A. (A.) pulchra) are restricted to the regions around Florida, the western islands of the Caribbean, and Barbados (Lesser Antilles), respectively. The global distribution of the subgenus Asteroporpa (Asteroporpa) is quite intriguing, and may reflect a very complex evolutionary and biogeographic history (or just a scarcity of collection material). These gorgonocephalids may occur in patches, which could further complicate the chances of collecting them. Additionally, the usual occurrence of Euryalida in deep water site has restricted the capture of larger numbers of specimens and species. As such, more collection efforts in the deeper waters off the Brazilian coast may provide more specimens of $A$. (A.) annulata as well as other representatives of the order Euryalida.

\section{ACKNOWLEDGMents}

We are grateful to Luis Ferreira Damasceno (Belo) and Luis Carlos for collecting and donating the specimen studied; and Dr. Carlo M. Cunha (Museum of Zoology of University of São Paulo) and Dr. Sabine Stöhr (Swedish Museum of Natural History) for kindly providing many references. Anne I. Gondim was supported by CAPES (Coordenação de Pessoal de Nível Superior, Brazilian Ministry of Education) through a Master's scholarship.

\section{LITERATURE CITED}

Appletans W, PG Bouchet, A Boxshall, K Fauchald, DP Gordon, BW Hoeksema GCB Poore, VM van Soest, S Stöhr, TC Walter \& MJ Costello. 2010. World Register of Marine Species. [on line] <http://www.marinespecies.org>

Alvarado JJ. 2011. Echinoderm diversity in the Caribbean Sea. Marine Biodiversity 41: 261-285.

Barboza CAM, FM Mendes, A Dalben \& LR Tommasi. 2010. Echinodermata, Ophiuroidea, Gorgonocephalus Leach, 1815: First report of the genus for the Brazilian continental margin. Checklist 6: 289-291.

Baker AN. 1980. Euryalinid Ophiuroidea (Echinodermata) from Australia, New Zealand, and the south-west Pacific Ocean. New Zealand Journal of Zoology 7: 11-83.
Borrero-Pérez GH, M Benavides-Serrato, Ó Solano \& GR Navas. 2008. Brittle-stars (Echinodermata: Ophiuroidea) from the continental shelf and upper slope of the Colombian Caribbean. Journal of Tropical Biology and Conservation 56(Suppl. 3): 169-204.

Clark AH. 1948. Two new starfishes and a new brittle-star from Florida and Alabama. Proceedings of the Biological Society of Washington 61: 55-66.

Clark HL. 1911. North Pacific ophiurans in the collection of the United States National Museum. Bulletin of the United States National Museum 75: 1-302.

Clark HL. 1915. Catalogue of recent ophiurans: based on the collection of the Museum of Comparative Zoology. Memoirs of the Museum of Comparative Zoology 25: 165-376.

Dujardin F \& H Hupé. 1862. Histoire naturelle des Zoophytes Échinodermes comprenant la description des crinoïdes, des ophiurides, des astérides, des échinides et des holothurides, 628 pp. Librairie encyclopédique de Roret, Paris.

Fell HB. 1962. Evidence for the validity of Matsumoto's classification of the Ophiuroidea. Publications Seto Marine Biological Laboratory 10: 145-152.

Grohmann PA. 2006. Importância dos acompanhamentos de longa duração no estudo da biodiversidade: exemplo da fauna de hidróides (Cnidaria) da Baía do Espírito Santo. Floresta e Ambiente 13: 97-112.

Hendler G \& JE Miller. 1984. Feeding behavior of Asteroporpa annulata, a gorgonocephalid brittlestar with unbranched arms. Bulletin of Marine Science 34: 449-460.

Hendler G, JE Miller, DL Pawson \& PM Kier. 1995. Sea stars, sea urchins, and allies: echinoderms of Florida and the Caribbean, 390 pp. Smithsonian Institution Press, Washington.

Hyman LH. 1955. The invertebrates: Echinodermata - The coelomate bilateria. Volume 4: 1-763. McGraw-Hill Book Company, New York.

Laguarda-Figueras A, FA Solís-Marín, A Durán-González, C Ahearn, BE Buitrón-Sánchez \& J Torres-Veja. 2005. Equinodermos (Echinodermata) del Caribe Mexicano. Revista de Biologia Tropical 53(Supl. 3): 109-122.

Ljungman AV. 1867. Ophiuroidea viventia huc usque cognita enumerata. Öfversigt af Kongelige Vetenskapsakademiens Forhandlingar Stockholm 1866: 303-336.

Lyman, T. 1869. Preliminary report on the Ophiuridae and Astrophytidae dredged in deep water between Cuba and the Florida Reef by L. E. Pourtales. Bulletin Museum of Comparative Zoology Harvard College 1: 309-354.

Lyman T. 1882. Report on the Ophiuroidea dredged by H. M. S. 'Challenger' during the years 1873-1876. Report of the Scientific Results of the Voyage of H. M. S. Challenger during 1873-1876, Zoology 5: 1-387. 
Lütken CF. 1856. Bidrag til Kundskab om Slangestjernerne. II. Oversigt over de vestindiske Ophiurer. Videnskabelige Meddelelser fra Danske Naturhistorisk Forening i Kjøbenhavn 7: 1-19.

Matsumoto H. 1917. A monograph of Japanese Ophiuroidea, arranged according to a new classification. Journal of the College of Science, Imperial University of Tokyo 38: 1-408.

McClintock JB, T Hopkins, K Marion, S Watts \& G Schinner. 1993. Population structure, growth and reproductive biology of the gorgonocephalid brittlestar Asteroporpa annulata. Bulletin of Marine Science 52: 925-936.

Mortensen T. 1933. Echinoderms of South Africa (Asteroidea and Ophiuroidea). Videnskabelige Meddelelser fra Dansk Naturhistorisk Forening i Kjøbenhavn 93: 215-490.

Okanishi M \& T Fujita. 2011. Two new species of the subgenus Asteroporpa (Asteromoana) (sic) (Ophiuroidea: Euryalida: Gorgonocephalidae) from Japan. Zootaxa 2751: 25-39.

Rosemberg, R, S Dupont, T Lundälv, HN Sköld, A Norkko, J Roth, T Stach \& M Thorndyke. 2005. Biology of the basket star Gorgonocephalus caputmedusae (L.). Marine Biology 148: 43-50.
Stöhr S \& T O'Hara. 2007. World Ophiuroidea database. [online] <http://www.marinespecies.org/ophiuroidea>

Tommasi LR. 1999. Echinodermata Recentes e Fósseis do Brasil. Invertebrados Marinhos Registrados no Litoral Brasileiro. [on line] <http://www.bdt.fat.org.br/ zoologia/ echinodermata>

Verrill AE. 1899. Report on the Ophiuroidea collected by the Bahama Expedition from the University of Iowa in 1893. Bulletin from the Laboratory of Natural History of the State University of Iowa 5: 1-86.

Verrill AE. 1900. VII.-North American Ophiuroidea. I. Revision of certain families and genera of West Indian ophiurans. II. A faunal catalogue of the known species of West Indian ophiurans. Transactions of the Connecticut Academy of Arts and Sciences 10: 301-386.

Viada ST \& SD Cairns. 2007. A new species of Nicella (Anthozoa: Octocorallia) from the Western Atlantic. Proceedings of the Biological Society of Washington 120: 227-231.

Received 26 July 2011 and accepted 13 December 2011 